\title{
Geographic and Dynamic Heterogeneity of Home Ownership
}

\author{
Jørgen Lauridsen \\ Department of Business and Economics \\ University of Southern Denmark, jt1@sam.sdu.dk
}

Campusvej 55, DK-5230 Odense M, Denmark, Phone +45 65502142

Niels Nannerup \& Morten Skak

Department of Business and Economics

University of Southern Denmark, nna@sam.sdu.dk $\&$ mos@sam.sdu.dk

Campusvej 55, DK-5230 Odense M, Denmark

Aknowledgement: The paper is written as a part of the Center for Housing and Welfare - RealDania

Research Project and the CARINAS project. Economic support from RealDania is acknowledged. 


\begin{abstract}
.
Determination of the demand for home ownership is analysed. Determinants include prices and short- and medium-term price changes, public regulation (regulation of house rent, housing subsidies, taxation), competition from alternative residence forms (measured by supply of subsidized housing), social composition of population (age, social benefit receivers, household composition, civil status, education, nationality), economic ability (income), and congestion (measured by population density and degree of urbanisation). The study applies Danish aggregate data for 270 Danish municipalities, available annually for the period 1999-2004. The effects of determinants on home ownership rates are allowed to be heterogeneous by years and municipalities using temporally and geographically expanded coefficients. Considerable parametric heterogeneity over time as well as across municipalities is found, even when residual dynamic heterogeneity and interdependency as well as residual spatial spillover is controlled for.
\end{abstract}

\title{
JEL Classifications
}

C21; C33; P25; R21; R31.

\section{Keywords}

Housing market; demand for home ownership; SUR; spatial spillover; spatial heterogeneity 


\section{Introduction}

A recent study (Lauridsen et al., 2006a) established an econometric model for the fraction of homes that are owner occupied in Denmark for the period 1999 to 2004. They summarised determinants of demand for homeownership. Theoretical determinants included prices and short- and medium-term price changes, public regulation (regulation of house rent, housing subsidies, taxation), competition from alternative residence forms (measured by supply of subsidized housing), social composition of population (age, social benefit receivers, household composition, civil status, education, nationality), economic ability (income), and congestion (measured by population density and degree of urbanisation). Issues related to the application of pooled cross sectional data were further discussed. Lauridsen et al. (2006a) included parametric instability over time, adjustment for dependency caused by repeated observation, and identification of the effect of prices on homeownership rates. It was found that parametric instability over time could be mostly ascribed to time trends in the parameters so that a simplified specification with common parameters across time, combined with time interactions, could be established.

Their study, however, ignored important issues related to spatial variation of the data applied. It is well known from studies concerning small area variation that it is necessary to control for spatial spillover in order to obtain proper conclusions regarding effects of determinants (Anselin, 1988; Anselin \& Bera, 1998; Anselin, 2000). This evidence readily pertain to the study of Lauridsen et al. (2006a): The housing market is not restricted to act within the borderlines of each single municipality. Rather, market conditions and market behaviour of contiguous municipalities may be expected to spill over between the municipalities. Thus, solely assuming the housing market behaviour of a municipality to be conditioned on the determining factors of this only municipality may well lead to skewed conclusions.

Specifically, it is the purpose of the present study to add to the results of Lauridsen et al. (2006a) by analysing the determinants of homeownership while controlling simultaneously, not only for dynamic heterogeneity, but also for spatial heterogeneity and spatial spillover effects. 
Part 2 of the present study briefly summarises the theoretical foundations from Lauridsen et al. (2006a) regarding determinants of homeownership rates. The applied data are briefly described in Part 3, upon which Part 4 outline methodological aspects. Spatial and temporal parametric heterogeneity is accounted for using parametric expansion. As pooled data are applied, a Seemingly Unrelated Regression (SUR) framework is advocated in order to capture dynamic patterns efficiently. Further, potential spatial spillover is controlled for by extending the SUR with a spatially autocorrelated (SAC) residual specification. Next, Part 5 outlines the estimation results and throughout demonstrates the fallacies of not simultaneously controlling for parametric heterogeneity, as conclusions regarding effects on homeownership rates of determinants varies heavily across the adjusted and non-adjusted specifications. Finally, Part 5 rounds off with a few comments and suggestions.

\section{Demand for owner occupied homes in Denmark}

We address the basic household choice of owning or renting a residence, focusing on home ownership by considering the demand for owner occupied residential units relative to total demand for these units. Based on Danish data, empirically significant determinants for this fraction are identified. Theoretically speaking, a household choose to own a dwelling if 'owning' is the outcome of its utility maximization given specific economic conditions for this household. The following discussion on determinants for home ownership draws on theoretical findings by among others Linneman (1986), Rothemberg et al (1991), Hansen \& Skak (2005), and Elsinga \& Hoekstra (2004). For a broader discussion of the theoretical basics see Lauridsen et al (2006a). In addition Atterhög (2005) surveys recent empirical studies on homeownership determinants from various countries.

In general, house prices and property values impact on ownership rates as mainly low income groups may be expected to reduce or delay demand for ownership occupation when rising prices occur. As price changes over longer periods also lead to changing price expectations this may again affect demand of dwellings, the consequence being that there is no unique relationship between owner occupations and house prices, but rather distinctive short term and a medium to long term relationships. 
Various forms of government intervention in housing markets via taxation and subsidization tend to capitalize in market prices and may as well affect relative price expectations for owned and rented dwellings. These interventions may therefore play a significant role for the choice of tenure type. The most important tax and subsidy measures in the Danish housing market will be tested for directly or indirectly as explanatory factors in the analysis. We thus include the real property tax rate. Further, as rent subsidies are commonly offered to renters, we test for the influence of this policy by considering the share of households and the share of the population receiving rent subsidies.

In industrialised countries mortgage loans typically constitute the major share of real estate finance. Mortgage terms and credit rating of households by lender institutions are likely to depend on a variety of individual characteristics. Chiuri \& Japelli (2004) provide empirical evidence from 14 countries that the mortgage availability affects home ownership distribution across age groups primarily due to income differences between the groups. Further, Canner \& Smith (1991) find that ethnicity matters for mortgage availability. Other factors that may affect credit rating are educational level and job perspectives. In the analysis we test for such characteristics.

Comparing advantages and disadvantages of ownership relative to rented dwellings may help identifying further potential determinants for the analysis. In more respects there are additional costs of owning rather than renting. The theoretical literature points to disadvantages of owners as to switching costs of moving (salaries to real estate agencies and lawyers, uncertainty about sales prices etc.) which thereby cause relatively low geographical mobility of owners. This indicates that individuals being more inclined to move (such as younger people, unmarried people, and younger couples without children) may choose rented dwellings. In addition Linneman (1986) points out that high production efficiency by landlords (i.e. as to maintenance costs) in high density areas are an important reason why ownership rates tend to fall from country side to urban areas. We seek evidence for this hypothesis by testing the significance of population density. One advantage of ownership is the wide scope for individual adaptation of the residence, and households clearly put different value on such an option. Preferences for housing autonomy may differ with age and career position as younger couples plan to have 
(more) children and educated people expect increasing future income. Further, one can argue that self employed people may be more individualistic oriented than employees and for that reason prefer home ownership.

It appears from these reasoning however that the incentives for choosing tenure type are mixed for some of these groups. For instance, while younger couples may evade switching costs of moving by being renters they may on the other hand prefer ownerships for reasons of housing autonomy (which in some sense can provide the same services as obtained from moving to a new residence). The same arguments in principle also apply to divorced people (anticipating future marriage).

In all these considerations lead us to test the variables shown in Table 1 for empirical significance in explaining homeownership rates in Denmark.

[Table 1 around here]

\section{Data}

The data to be applied are aggregate cross section data observed for 270 Danish municipalities (5 municipalities on the island of Bornholm were omitted due to data problems) annually from 1997 to 2004. Data were collected from five sources: The Statistical Bank at Statistics Denmark, the Key Figure Base [Nøgletalsbasen] at the Ministry of the Interior, the Ministry of Urban and Housing Affairs' (2000) report on regulation of housing rents, and the Danish Tax Authority's [Told \& Skat] (2004) report on property sales prices. Table 2 presents an overview of the data applied, including variable short-hands, definitions and a few descriptive statistics.

[Table 2 around here]

Figure 1 shows the distribution of the home ownership rates (averaged over years) across municipalities. Several indications of spatial clustering are observed for these. Thus spatial spillover may potentially be present and 
needs to be adjusted for. Likewise several of the explanatory variables exert spatial clustering which may potentially lead to spatial spillover; see Lauridsen et al. (2006b) for detailed maps of these.

[Figure 1 around here]

\section{Methodology}

Assuming a cross-section of $N=270$ municipalities, the basic linear regression model specifies

$$
y_{t}=X_{t} \beta+v_{t}, \quad v_{t} \sim N\left(0, \sigma^{2} I_{N}\right)
$$

where $X_{t}$ is an $N$ by $K$ dimensional matrix of explanatory variables, $y_{t}$ is an $N$ dimensional vector of endogenous observations, $\beta$ is a $K$ dimensional vector of coefficient, and $v_{t}$ a residual with variance $\sigma^{2}$.

A restrictive assumption of the model (1) is that $\beta$ is constant over time and across provinces. In order to allow these coefficients to vary across years and municipalities, we apply expansions (Casetti, 1997, Jones \& Casetti, 1992), i.e. the effect of the $k^{\prime}$ th regressor $\left(k=0, . . K\right.$, with the convention that $\beta_{0}$ is the constant term, i.e.

$\left.X_{0}=1\right)$ is specified as

$$
\beta_{k}=\alpha_{0 k}+\alpha_{T k} T+\alpha_{H k} H+\alpha_{H^{2} k} H^{2}+\alpha_{V k} V+\alpha_{V^{2} k} V^{2}+\alpha_{H V k} H V
$$

where $\alpha_{j k}\left(j=T, H, H^{2}, V, V^{2}, H V\right)$ are coefficients, $T$ is a time trend, and $H$ and $V$ the horizontal (west to East) and vertical (South to North) coordinates of the geographical midpoints of the regions respectively, The square terms $H^{2}$ and $V^{2}$ together with the interaction term $H V$ are inserted to allow for non-linear and diagonal dispersion of the $\beta$ coefficients. Inserting (2) in (1) gives the expanded specification

$$
Y_{t}=\sum_{k=0}^{K}\left\{\alpha_{0 k} X_{t k}+\alpha_{T k}\left(T X_{t k}\right)\right.
$$




$$
\left.+\alpha_{H k}\left(H X_{t k}\right)+\alpha_{H^{2} k}\left(H^{2} X_{t k}\right)+\alpha_{V k}\left(V X_{t k}\right)+\alpha_{V^{2} k}\left(V^{2} X_{t k}\right)+\alpha_{H V k}\left(H V X_{t k}\right)\right\}+v_{t} .
$$

Operationally, the expanded specification (3) can be estimated by applying multiplicative interaction terms between $X_{k}$ and the $T, H, H^{2}, V, V^{2}$ and $H V$ variables. Next, the $\beta_{k}$ coefficients for each municipality by each time period, say $\beta_{\text {kit }}$, can be evaluated from (2) together with their standard errors, as the $\beta$ parameters are simple linear functions of the $\alpha$ parameters. Finally, the averages for each time period and the averages for each municipality are readily obtained to serve illustrative and interpretational purposes.

In order to obtain efficient estimation results, the structure of the residuals needs consideration. First, to account for residual spatial spillover, the spatially autocorrelated (SAC) specification (Anselin, 1988) is applied to the residual of (3), i.e.,

$$
\mathrm{v}_{t}=\lambda W \mathrm{v}_{t}+\varepsilon_{t}
$$

where $\lambda$ is an autocorrelation parameter and $W$ an $N \times N$ contiguity matrix defined by letting $w_{i j}$ equal $\frac{1}{n_{i}}$ if municipalities $i$ and $j$ are neighbours $(i \neq j)$ and 0 otherwise, as $n_{i}$ is the number of neighbours to municipality $i$. Intuitively, the product $W v_{t}$ defines a variable, which for each municipality holds the average of $v_{t}$ in the neighbouring provinces. Next, when applying pooled data for $T$ periods, the residuals are inter-correlated across time, and the variances for the cross-sections vary over time. Thus, between any two time periods, the residual covariance is specified as

$$
E\left(\varepsilon_{t} \varepsilon_{s}{ }^{\prime}\right)=\sigma_{t s}^{2} I_{N}, t, s=1, . ., T
$$

The model defined by (3)-(4)-(5) was estimated efficiently by applying the following Maximum Likelihood approach: We did a grid search of the relevant values of $\lambda$ from -1 to +1 . Conditioned on each value of $\lambda$, a Feasible Generalised Least Squares (F-GLS) estimation (Zellner, 1962) was applied to (3) using $\left(I_{N}-\lambda W\right) y_{t}$ 
instead of $y_{t}$ and $\left(I_{N}-\lambda W\right) X_{t}$ instead of $X_{t}$ to obtain SUR estimates of $\beta$. Finally, the set of results which maximized the log likelihood function was selected.

To provide devices for comparison of alternative models, some quantities are applied. One is a pseudo-R-square $\left(R^{2}\right)$, calculated as the square of the correlation between $y$ and its predicted values. A second device, which alike the R-square measures can be used as a goodness-of-fit measure for comparison of models is the familiar Akaike Information Criterion (AIC). Finally, Wald tests for the expansions are provided, i.e., for the hypotheses that $\alpha_{T}$ and/or $\left(\alpha_{H}, \alpha_{H^{2}}, \alpha_{V}, \alpha_{V^{2}}, \alpha_{H V}\right)$ equal 0.

\section{Results}

The first column of Table 3 reports the unexpanded baseline SAC-SUR model. Several of the explanatory variables are found to be significant. This is the case for the short - and medium term price changes, while a weakly significant effect of prices is seen. Considering regulation, all variables are found to exert the expected negative effects on home ownership. Property tax rates and personal tax rates hardly exert any influence. For property taxes, there is even a weak indication of a positive relation to home ownership, which contradicts the theoretical expectation. Congestion exerts the expected negative effect, as population density as well as urbanization is negatively related to home ownership rates. Turning to demographic composition, it generally seems to be the case that high proportions of inhabitants in any age group over 18 years (and, consequently, low proportions of youngsters and children below 18) exert negative effects on home ownership. On the other hand, presence of many households with adult children seems to raise home ownership. Presence of households without children and youngsters seems to be unrelated to home ownership. While a large positive coefficient is reported for this determinant, an extraordinary large standard error of the coefficient seems to indicate considerable heterogeneities of its relationship to home ownership. Several significant relationships are further seen to indicators of social composition of population While proportion of widowed, further educated and early retired seem to be unrelated to home ownership, large negative effects of proportions of divorced, unmarried, social benefit receivers and inhabitants from third countries are evident. Finally, presence of residual spatial 
spillover is evident as indicated by the significantly positive $\lambda$ coefficient, just as the presence of considerable intertemporal residual correlations and heteroscedasticity are confirmed by the test for diagonality.

[Table 3 around here]

The remainder of Table 3 reports on the expanded SAC-SUR model. Quick glances through each column reveal that considerable parametric heterogeneity is present across years as well as in any of the geographical dimensions. This impression is further supported by the Wald tests, which are strongly significant for any of the dimensions. Finally, the spatial spillover seems to be removed by the spatial expansion, as the $\lambda$ coefficient is substantially reduced and insignificant. Opposed to this, the SUR adjustment still seems to be relevant as indicated by the significant diagonality tests.

As the raw coefficients of the expanded model are not very supportive for interpretational purposes, the averages of coefficients by year are reported in Figure 2, together with 95 percent confidence intervals. The effect of prices seems to be negative and growing through years and turning significant (at the 5 percent level) after 2000. The effect of short term price changes also turns slightly more negative, but the confidence interval spreads considerably in the last years, thus indicating an increasing cross-municipal heterogeneity in this effect, i.e. a larger dispersion between these areas where the price change affects heavily and those where they hardly do. The medium term price change seems to loose importance through years, as it drops steadily from significantly positive in 1999 - 2001 and even approximates zero in 2004. A potential explanation may be that the expectation of further price increases, which were optimistic in the late 90es, rather turned into discussions of whether a price bubble were to be expected. Turning to effects of regulation variables, the negative effects of rent regulation and supply of subsidised housing on home ownership seem to be slightly reduced, while the negative effects of cash payment housing subsidies and rent subsidies seem to be boosted. The tax variables as well as income (as measured by tax base) are insignificant throughout the period. Regarding congestion, the stable negative coefficient of population density seem to confirm that this effect is unchanged, while the slightly reduced coefficient of urbanisation seem to indicate that the congestion effect is turning slightly less important. Considering age composition, the effects reported for the unexpanded model seem to be increased over year, i.e. 
high proportions of adults (and thus low proportions of children) exert an increasing negative effect on home ownership. On the other hand, the positive effect of having many households with children over 18 seems to increase. The effect of having many households without children below 18 exert an interesting pattern, as it drops from significantly positive to being almost significantly negative in 2004 . Turning to the effects of social composition, it is noticeable that the negative effects of "late singleness", i.e. divorce and widowhood, seem to be reduced strongly. A potential explanation may be the improved economical conditions for these groups, due to larger pension savings and higher incomes. It is also noticeable that the effect of inhabitants from third countries is increasingly negative, which may be related to worsened economic conditions of this group. Finally and slightly surprising - the effect of unemployment seem to increase and even become significantly positive. A potential explanation for this may be the distinctive geographical pattern of the unemployment variable, as unemployment concentrates in rural areas - especially in the Northern part of the country - where home ownership also concentrate due to the lack of available rental housing (Lauridsen et al., 2006b).

[Figure 2 around here]

Figure 3 provides a device for understanding the geographical patterning of the relationships between determinants and home ownership, as it reports the $t$ values for the averages by municipalities of the expanded coefficients. The effects of prices are seen to exert considerable geographical variation. The expected significantly negative impact of prices is present in the capitol area, the middle part of Zeeland and the Eastern part of Funen, while prices are not significantly relate to ownership in the entire Jutland. On the other hand, short term price changes exert a significantly negative impact in most of the country with northern Jutland as a predominant exception. Medium term price change exerts the expected positive relation to home ownership in an East-West belt across the middle of the country, which essentially spans the 6 largest Danish cities, while the relationship is insignificant in the peripheral areas of Northern and Southern Jutland. This, the medium term price expectation seem to be in play predominantly in areas surrounding larger cities. Turning to presence of rent regulation, an interesting relationship between the coefficient and the geographical distribution of the variable is seen: Presence of rent regulation clusters strongly on Zeeland, while absence of regulation clusters in the Western part of Jutland (Lauridsen et al., 2006b). For these areas, the expected negative effect is confirmed. 
Thus, the absence of regulation in Western Jutland increases home ownership, while the presence of regulation on Zeeland reduces home ownership. The effect of amount of subsidised housing is significantly negative throughout, but strongest in a belt spanning Zeeland, Funen and Southern Jutland. Housing subsidies exert a significantly negative impact on home ownership in the Middle to Northern parts of Zeeland and Jutland, while the effect of rent subsidies is negative throughout the country except for a belt of municipalities along the Western coast of Jutland. Regarding taxation, it is seen that property taxes are unrelated to home ownership in most of the country except for the Capitol area, where a significantly positive relationship is present, presumably indicating that municipalities in this area can increase property taxes without experiencing a reduction of the demand for owner occupied housing. For income tax rates, the effect is mostly insignificant, with the exception of a small cluster of municipalities North of the Capitol area, where a significantly negative relationship is present, presumably expressing a common factor phenomenon, i.e. personal incomes are high in this area, which simultaneously enable the municipalities to maintain low tax rates and stimulate home ownership. The effect of income (measured by tax base) is insignificant throughout except for a cluster of municipalities in the NorthWestern Jutland, where the expected positive relationship is present. As the tax base is relatively low in this area (Lauridsen et al., 2006b), it seems to be the case that the tendency to home ownership is dampened by low incomes. Considering congestion, the expected negative effect is present throughout with a few exceptions. Population density is insignificant in the southern Zeeland, while urbanisation is significant in an East-West belt spanning the Capitol area, Northern Funen and Middle-Eastern Jutland, which contains the 6 largest Danish cities, and insignificant elsewhere with an exception of a small cluster in the very Northern Jutland, where a positive relationship stands out. Turning to demographic composition, a somewhat mixed picture occurs. Proportion of 7-16 year old exerts a negative effect on home ownership in the Middle-Eastern Jutland, but is insignificant elsewhere. The negative effect of 17-25 year old is especially expressed outside Middle-Western Jutland and southern Zeeland. A more or less likely picture is seen for 26-35 and 36-66 year old, while proportion of elder $(67+)$ is significantly negative throughout with the exception of two small clusters in the peripheral areas of Western Jutland and Southern Zeeland. Regarding household composition, a significantly positive relationship between proportion of households with adult children and home ownership is seen in the predominantly rural areas of Northern and Western Jutland. Proportion of households without children under 
18 is insignificant throughout, with an exception of a small cluster in the peripheral Southern Zeeland, where a significantly positive relationship is present. The effects of social composition exert considerable geographical variation. Thus, a weakly significant effect of widowhood is seen in the Northern Jutland and Zeeland, while divorced is significantly negative throughout with an exception of an insignificant belt along the peripheral West coast of Jutland. Unmarried exerts the expected negative impact except for the area of Funen and some peripheral areas in the Northern and Southern Jutland and Southern Zeeland. Education is negatively related to home ownership around the Capitol area and insignificant elsewhere, with an exception of a small cluster in Southern Jutland, where a positive relationship is confirmed. Proportion of social disability pensioned exerts a negative impact in the aforementioned East-Western belt spanning the 6 largest cities, and insignificant elsewhere. A negative effect of proportion of social benefit receivers is exerted in a large cluster spanning the Middle Jutland, Northern Funen and the very Western Zeeland, while the effect is insignificant elsewhere. While unemployment is mainly insignificant, it is positively related to home ownership in the Northern Jutland, presumably because this area during the period experienced a considerable outsourcing of large production companies, whereby many previously employed home owners were simultaneously stuck to their houses and caught in an area with low employment opportunities. Finally, proportion of foreigners is significantly negatively related to home ownership throughout with exceptions of Eastern and Southern Zeeland and Western Jutland.

(Figure 3 around here)

As mentioned above, the insignificant spatial spill-over parameter indicates that the spatial expansion seems to capture tendencies to spatial spill-over and spatial clustering well. This impression is confirmed by Figure 4, which shows the standardised residuals by municipalities. With single exceptions, the standardised residual is within a reasonable band of $+/-1.96$. Though there seems to be weak tendencies to positive and negative clustering within this band, these tendencies are statistically and practically irrelevant.

[Figure 4 around here]

\section{Conclusions}


While previous knowledge regarding effects of determinants on home ownership is confirmed, it is revealed that considerable dynamic as well as geographical variation in these effects is present and should be accounted for in order to obtain a deeper understanding of the functioning of important key determinants of the housing market. Thus, the expected negative effect of price is confirmed, and it is found that this effect is strengthened over years in which prices increased steadily, but the effect is found to be significant for only a restricted geographical area spanning the capitol area, western Zeeland and Funen and insignificant especially in peripheral areas. During the same period, short term price change exerts an increasing negative impact on home ownership, but the effect turns considerably more heterogeneous across geographical areas in the late years, and the effect seems to be less relevant for peripheral areas. While a positive effect of medium term price changes is confirmed for areas surrounding larger cities, the effect is found to decrease over years, presumably reflecting uncertain expectations caused by a potential price bubble on the housing market. Regulation exerts the expected negative impact, but the effect seems to increase over years for regulation in the form of cash payments, while the effects of applying supply side regulation in the form of supply of subsidised housing and presence of rent regulation seems to reduce. Geographically heterogeneous patterns of regulation effects are further revealed, with clear tendencies to central-peripheral and urban-rural dispersions. Finally, the effects of taxations are weak and changes only marginally through the years, and the geographical patterns of these effects rather indicate distinctive geographical presences of common factors causing effects reverse to those expected. 


\section{References}

Anselin L (1988). Spatial econometrics: Methods and models, North-Holland, Kluwer Academic Publishers.

Anselin L (2000). Spatial Econometrics. In Baltagi B (ed) A Companion to Theoretical Econometrics, Oxford, Blackwell Publishers.

Anselin L \& Bera A (1998). Spatial dependence in linear regression models with an introduction to spatial econometrics. In Ullah A, Giles D (eds) Handbook of applied economic statistics, New York, Marcel Dekker.

Atterhög M (2005). Importance of Government Policies for Home Ownership - An International Survey and Analysis. In Doling J, Elsinga M (eds) Home Ownership: Getting In, Getting From, Getting Out, Part II, Delft, Delft University Press.

Canner G \& Smith D (1991). Home Mortgage Disclosure Act: Expanded Data on Residential Lending. In: Ross

D, Yinger J (eds) The color of credit. Mortgage discrimination, research methodology, and fair-lending enforcement, Cambridge, MIT Press.

Casetti E (1997). The Expansion Method, Mathematical Modeling, and Spatial Econometrics. International Regional Science Review, 20, 9-33.

Chiuri MC \& Jappelli T (2003). Financial market imperfections and home ownership: A comparative study. European Economic Review, 47, 857-875.

Danish Tax Authority (2004). Ejendomssalg 1. halvår 2004 [Property sales 1. half-year 2004], Copenhagen, Danish Tax Authority.

Elsinga M \& Hoekstra J (2004). Homeownership and housing satisfaction: a study of the literature and an analysis of the European Community Household Panel, Delft, Delft University of Technology, OTB Research Institute. 
Hansen JD \& Skak M (2005). Economics of Housing Tenure Choice, Odense, University of Southern Denmark, Department of Business and Economics.

Jones JP \& Casetti E (1992). Applications of the Expansion Method, London, Routledge.

Lauridsen J, Nannerup N \& Skak M (2006a). Explaining Homeownership Rates in Danish Municipalities. In Doling J, Elsinga M (eds) Home Ownership: Getting In, Getting From, Getting Out, Part II, Delft, Delft University Press.

Lauridsen, J, Nannerup, N \& Skak, M (2006b). Dynamic and Geographic Patterns of Home Ownership [online]. Available: http://www.sam.sdu.dk/economics/edp.html

Linneman P (1986). A New Look at the Homeownership Decision. Housing Finance Review, 5, 159 - 187.

Ministry of Urban and Housing Affairs (2000). Huslejen 1999 [The house rent 1999], Copenhagen, Ministry of Urban and Housing Affairs.

Rothemberg J, Galster GC, Butler RW \& Pitkin J (1991). The Maze of Urban Housing Markets. Theory, Evidence, and Policy, Chicago, The University of Chicago Press.

Zellner A (1962). An Efficient Method of Estimating Seemingly Unrelated Regressions and Tests of Aggregation Bias. Journal of the American Statistical Association, 58, 977-992. 
Table 1. Variables affecting homeownership rates

\begin{tabular}{|c|c|}
\hline Variable & Explanation \\
\hline $\begin{array}{l}\text { Prices } \\
\text { Actual price }(-) \\
\text { One-year price change }(-) \\
\text { Three-year average price change } \\
(+)\end{array}$ & $\begin{array}{l}\text { High prices and short-run price increases make it difficult to buy home. } \\
\text { Medium-term price changes stimulate the expectation of future increasing } \\
\text { prices and thus the propensity to buy. }\end{array}$ \\
\hline $\begin{array}{l}\text { Favourable tax treatment of } \\
\text { bomeowners } \\
\text { Tax bracket }(+)\end{array}$ & $\begin{array}{l}\text { A favourable tax treatment triggered by ownership tends to raise } \\
\text { ownership rates; such treatment, e.g. a low imputed rent, is typically more } \\
\text { valuable for higher income tax brackets. }\end{array}$ \\
\hline $\begin{array}{l}\text { Rent subsidy (-) } \\
\text { Rent control (-) } \\
\text { Urban restriction on ownership (-) }\end{array}$ & $\begin{array}{l}\text { Homeownership rates are reduces if an income subsidy is triggered by } \\
\text { renting vs. owning. If rent control artificially keeps the rent on rented } \\
\text { homes below the market equilibrium this also reduces demand for owned } \\
\text { housing. If, e.g. for social reasons, only a fraction of homes can be owned, } \\
\text { this potentially reduce homeownership rates. }\end{array}$ \\
\hline $\begin{array}{l}\text { Financial capacity } \\
\text { Income }(+) \\
\text { Nationality (?) } \\
\text { Educational level }(+) \\
\text { Other personal characteristics } \\
\text { Special life events (e.g. divorce, } \\
\text { bequest, lottery) }\end{array}$ & $\begin{array}{l}\text { With asymmetric information on financial markets, various indicators of } \\
\text { borrowers (homeowners) repayment ability will influence homeownership } \\
\text { rates. }\end{array}$ \\
\hline $\begin{array}{l}\text { Expected occupation time } \\
\text { Age }(-) \\
\text { Rate of "under education" (-) } \\
\text { Job type }\end{array}$ & $\begin{array}{l}\text { Ownership starts with closing or contracting costs that have to be } \\
\text { balanced against benefits in each occupation year. If the expected number } \\
\text { of occupation years is low, ownership rates tend to fall. Expected } \\
\text { occupation years may also fall with some job types. }\end{array}$ \\
\hline $\begin{array}{l}\text { Production efficiency for landlords vs. } \\
\text { owner-occupiers } \\
\text { Congestion (-) }\end{array}$ & $\begin{array}{l}\text { Where many live together landlord scale economies for production of } \\
\text { housing services may be pronounced. }\end{array}$ \\
\hline $\begin{array}{l}\text { Households differs in benefit from } \\
\text { adapting their home } \\
\text { Self employed }(+) \\
\text { More than one child }(+) \\
\text { High rent area }(-)\end{array}$ & $\begin{array}{l}\text { Idiosyncratic variations in the benefit households or individuals get from } \\
\text { individual adaptation of homes leads to a market screening where owners } \\
\text { benefit most. High rents reduce net benefit most for owners and squeeze } \\
\text { some owners into renters. }\end{array}$ \\
\hline $\begin{array}{l}\text { Social heritage } \\
\text { Parents tenure choice }\end{array}$ & People tend to demand the type of dwelling they used to live in as child. \\
\hline $\begin{array}{l}\text { Lifestyle } \\
\text { Rate of single households (-) }\end{array}$ & $\begin{array}{l}\text { Modes of living, e.g. free single life vs. tied family life influence ownership } \\
\text { rates. }\end{array}$ \\
\hline
\end{tabular}

Note: A (+) indicates a positive correlation between the variable and the homeownership rate.

Source: Lauridsen et al. (2006a). 


\section{Table 2. Data applied}

\begin{tabular}{|c|c|c|c|c|}
\hline Variable short-hand & Definition & $\begin{array}{l}25 \% \\
\text { quartile }\end{array}$ & Median & $75 \%$ quartile \\
\hline $\begin{array}{l}\text { Home ownership } \\
\text { (dependent variable }\end{array}$ & $\begin{array}{l}\% \text { of housing units occupied by owner (cooperative housing and student hostels } \\
\text { omitted)(1) }\end{array}$ & 62.00 & 71.00 & 76.00 \\
\hline Price & Average sales price (real DKK) per square meter of one-family houses ${ }^{(4)}$ & 51.86 & 55.73 & 73.48 \\
\hline Short term price change & Defined as $\left(\right.$ PRICE $_{i, t}-$ PRICE $\left._{i, t-1}\right) /$ PRICE $_{i, t-1}$ & 0.034 & 0.055 & 0.079 \\
\hline Medium term price change & Defined as $\left(\right.$ PRICE $\left._{\mathrm{i}, \mathrm{t}}-\mathrm{PRICE}_{\mathrm{i}, \mathrm{t}-3}\right) / \mathrm{PRICE}_{\mathrm{i}, \mathrm{t}-3}$ & 0.095 & 0.225 & 0.285 \\
\hline Subsidised housing & of population living in subsidized housing [almennyttige boliger] (2) & 5.00 & 9.00 & 17.00 \\
\hline Housing subsidy & $\%$ of households receiving housing subsidies [boligydelse] ${ }^{(2)}$ & 8.90 & 10.90 & 13.25 \\
\hline Rent subsidy & $\%$ of $15-66$ year old receiving rent subsidies [boligsikering] ${ }^{(2)}$ & 2.90 & 4.00 & 5.90 \\
\hline Regulated & Rent Regulation Act assumed by $2000(1=$ yes, $0=$ no) (3) & \multicolumn{3}{|c|}{ Proportion "yes" $=0.556$} \\
\hline Property tax & Real Property Tax (in 0/00) [Grundskyldspromille] (2) & 8.00 & 12.00 & 15.00 \\
\hline Tax rate & Municipal + county tax rate (in \%) [Udskrivningsprocent ${ }^{(2)}$ & 20.20 & 20.80 & 21.30 \\
\hline Tax base & Tax base [beskatningsgrundlag] per inhabitant (100.000 DKK) (2) & 9.94 & 10.97 & 12.10 \\
\hline Population density & Inhabitants per square kilometre $\left(10000^{(2)}\right.$ & 48 & 69 & 147 \\
\hline Urbanisation & $\%$ of population living in urban areas ${ }^{(2)}$ & 61.00 & 71.00 & 86.00 \\
\hline $7-16$ year & $\%$ of population aged $7-16^{(1)}$ & 11.90 & 12.90 & 13.90 \\
\hline $17-25$ year & $\%$ of population aged $17-25^{(1)}$ & 8.07 & 9.09 & 10.21 \\
\hline $26-35$ year & $\%$ of population aged $26-35^{(1)}$ & 11.74 & 12.82 & 13.89 \\
\hline 36-66 year & $\%$ of population aged $36-66^{(1)}$ & 40.55 & 42.33 & 44.27 \\
\hline $67+$ year & $\%$ of population aged 67 and over ${ }^{(1)}$ & 12.00 & 13.50 & 15.00 \\
\hline Widowed & $\%$ of population widowed ${ }^{(1)}$ & 5.91 & 6.61 & 7.37 \\
\hline Divorced & $\%$ of population divorced $(1)$ & 4.86 & 5.82 & 7.40 \\
\hline Unmarried & $\%$ of population unmarried ${ }^{(1)}$ & 41.91 & 43.54 & 44.80 \\
\hline Adult children & $\%$ of households with children over $18(1)$ & 7.68 & 8.76 & 9.88 \\
\hline No children & $\%$ of households without children under $18^{(1)}$ & 0.00 & 3.06 & 5.62 \\
\hline Educated & $\%$ of population with higher education $(2)$ & 11.50 & 13.60 & 16.45 \\
\hline Social disability pension & $\%$ of population on social disability pension [fortidspension] ${ }^{(2)}$ & 6.25 & 7.40 & 8.80 \\
\hline Social benefit receivers & $\%$ of population receiving social benefits [kontanthjalp] ${ }^{(2)}$ & 6.70 & 8.00 & 9.60 \\
\hline Unemployed & $\%$ of population (17-66 year) unemployed $(2)$ & 3.60 & 4.40 & 5.40 \\
\hline 3rd countries & $\begin{array}{l}\text { Number of citizens from countries outside EU, Scandinavia and North America } \\
\text { per } 10,000 \text { inh. (2) }\end{array}$ & 10.60 & 15.70 & 23.60 \\
\hline Finished new buildings & Finished new buildings $\left(\mathrm{m}^{2} \text { per capita) }\right)^{(1)}$ & 0.84 & 1.37 & 2.06 \\
\hline
\end{tabular}

Sources: (1) Statistics Denmark; (2) The Key Figure Base; (3) The Ministry of Urban and Housing Affairs; (4) The Danish Tax Authority. 
Table 3. Basic and expanded spatial SUR models.

\begin{tabular}{|c|c|c|c|c|c|c|c|c|}
\hline & \multirow{2}{*}{$\frac{\text { [1] Unexp. }}{\alpha_{0}}$} & \multicolumn{7}{|c|}{ [2] Expanded } \\
\hline & & $\alpha_{0}$ & $\alpha_{T}$ & $\alpha_{H}$ & $\alpha_{H H}$ & $\alpha_{V}$ & $\alpha_{V V}$ & $\alpha_{H V}$ \\
\hline Constant & $\begin{array}{l}159.03 * * * \\
(10.17)\end{array}$ & $\begin{array}{l}126.64 * * * \\
(22.906)\end{array}$ & $\begin{array}{l}2.285 \\
(3.365)\end{array}$ & $\begin{array}{l}15.916 \\
(16.191)\end{array}$ & $\begin{array}{l}39.987 \\
(25.497)\end{array}$ & $\begin{array}{l}18.889 \\
(19.632)\end{array}$ & $\begin{array}{l}22.380 \\
(24.351)\end{array}$ & $\begin{array}{l}39.015 \\
(36.899)\end{array}$ \\
\hline Price & $\begin{array}{l}-0.006^{*} \\
(0.004)\end{array}$ & $\begin{array}{l}-0.005 \\
(0.011)\end{array}$ & $\begin{array}{l}-0.002 \\
(0.002)\end{array}$ & $\begin{array}{l}-0.011^{*} \\
(0.007)\end{array}$ & $\begin{array}{l}0.007 \\
(0.010)\end{array}$ & $\begin{array}{l}0.001 \\
(0.008)\end{array}$ & $\begin{array}{l}-0.001 \\
(0.009)\end{array}$ & $\begin{array}{l}0.004 \\
(0.013)\end{array}$ \\
\hline $\begin{array}{l}\text { Short term price } \\
\text { change }\end{array}$ & $\begin{array}{l}-2.431 * * * \\
(0.643)\end{array}$ & $\begin{array}{l}-2.638 \\
(1.707)\end{array}$ & $\begin{array}{l}-0.303 \\
(0.599)\end{array}$ & $\begin{array}{l}1.359 \\
(0.896)\end{array}$ & $\begin{array}{l}0.162 \\
(1.527)\end{array}$ & $\begin{array}{l}1.619 \\
(1.165)\end{array}$ & $\begin{array}{l}-0.021 \\
(1.269)\end{array}$ & $\begin{array}{l}0.171 \\
(2.182)\end{array}$ \\
\hline $\begin{array}{l}\text { Medium term } \\
\text { price change }\end{array}$ & $\begin{array}{l}1.804 * * \\
(0.719)\end{array}$ & $\begin{array}{l}6.489^{* * *} \\
(1.846)\end{array}$ & $\begin{array}{l}-0.809 * * \\
(0.401)\end{array}$ & $\begin{array}{l}-0.198 \\
(1.117)\end{array}$ & $\begin{array}{l}0.534 \\
(1.796)\end{array}$ & $\begin{array}{l}-0.301 \\
(1.325)\end{array}$ & $\begin{array}{l}-3.367 * * \\
(1.474)\end{array}$ & $\begin{array}{l}0.634 \\
(2.530)\end{array}$ \\
\hline $\begin{array}{l}\text { Subsidised } \\
\text { housing }\end{array}$ & $\begin{array}{l}-0.480^{* * *} \\
(0.024)\end{array}$ & $\begin{array}{l}-0.370^{* * *} \\
(0.059)\end{array}$ & $\begin{array}{l}0.013^{* * *} \\
(0.003)\end{array}$ & $\begin{array}{l}0.054 \\
(0.042)\end{array}$ & $\begin{array}{l}-0.168^{* *} \\
(0.070)\end{array}$ & $\begin{array}{l}0.157 * * * \\
(0.059)\end{array}$ & $\begin{array}{l}-0.167^{* *} \\
(0.084)\end{array}$ & $\begin{array}{l}-0.122 \\
(0.109)\end{array}$ \\
\hline $\begin{array}{l}\text { Housing } \\
\text { subsidies }\end{array}$ & $\begin{array}{l}-0.088^{* * *} \\
(0.029)\end{array}$ & $\begin{array}{l}-0.099 \\
(0.088)\end{array}$ & $\begin{array}{l}-0.016 \\
(0.011)\end{array}$ & $\begin{array}{l}-0.222^{* * *} \\
(0.058)\end{array}$ & $\begin{array}{l}-0.040 \\
(0.125)\end{array}$ & $\begin{array}{l}-0.256^{* * *} \\
(0.082)\end{array}$ & $\begin{array}{l}-0.202^{*} \\
(0.116)\end{array}$ & $\begin{array}{l}-0.172 \\
(0.162)\end{array}$ \\
\hline Rent subsidies & $\begin{array}{l}-0.334 * * * \\
(0.058)\end{array}$ & $\begin{array}{l}-0.352^{* * *} \\
(0.128)\end{array}$ & $\begin{array}{l}-0.051^{* * *} \\
(0.018)\end{array}$ & $\begin{array}{l}-0.215^{* *} \\
(0.093)\end{array}$ & $\begin{array}{l}0.436^{* * *} \\
(0.140)\end{array}$ & $\begin{array}{l}0.052 \\
(0.115)\end{array}$ & $\begin{array}{l}-0.043 \\
(0.138)\end{array}$ & $\begin{array}{l}-0.029 \\
(0.203)\end{array}$ \\
\hline Regulated & $\begin{array}{l}-1.820^{* * *} \\
(0.476)\end{array}$ & $\begin{array}{l}-0.102 \\
(0.878)\end{array}$ & $\begin{array}{l}0.066 \\
(0.041)\end{array}$ & $\begin{array}{l}-0.659 \\
(0.780)\end{array}$ & $\begin{array}{l}-3.071 * * \\
(1.243)\end{array}$ & $\begin{array}{l}1.947^{* *} \\
(0.914)\end{array}$ & $\begin{array}{l}-1.464 \\
(1.064)\end{array}$ & $\begin{array}{l}3.257^{*} \\
(1.779)\end{array}$ \\
\hline Property tax & $\begin{array}{l}0.032^{*} \\
(0.018)\end{array}$ & $\begin{array}{l}-0.199 \\
(0.036)\end{array}$ & $\begin{array}{l}-0.004 \\
(0.004)\end{array}$ & $\begin{array}{l}0.077^{* *} \\
(0.031)\end{array}$ & $\begin{array}{l}0.103^{* *} \\
(0.048)\end{array}$ & $\begin{array}{l}0.023 \\
(0.037)\end{array}$ & $\begin{array}{l}0.053 \\
(0.035)\end{array}$ & $\begin{array}{l}0.048 \\
(0.074)\end{array}$ \\
\hline Tax rate & $\begin{array}{l}-0.076 \\
(0.071)\end{array}$ & $\begin{array}{l}0.068 \\
(0.152)\end{array}$ & $\begin{array}{l}0.005 \\
(0.019)\end{array}$ & $\begin{array}{l}-0.023 \\
(0.104)\end{array}$ & $\begin{array}{l}-0.297^{*} \\
(0.169)\end{array}$ & $\begin{array}{l}-0.044 \\
(0.127)\end{array}$ & $\begin{array}{l}-0.076 \\
(0.169)\end{array}$ & $\begin{array}{l}-0.007 \\
(0.261)\end{array}$ \\
\hline Tax base & $\begin{array}{l}0.030 \\
(0.046)\end{array}$ & $\begin{array}{l}0.066 \\
(0.116)\end{array}$ & $\begin{array}{l}-0.021 \\
(0.016)\end{array}$ & $\begin{array}{l}0.014 \\
(0.064)\end{array}$ & $\begin{array}{l}0.002 \\
(0.118)\end{array}$ & $\begin{array}{l}0.155 \\
(0.113)\end{array}$ & $\begin{array}{l}0.068 \\
(0.139)\end{array}$ & $\begin{array}{l}-0.069 \\
(0.175)\end{array}$ \\
\hline $\begin{array}{l}\text { Population } \\
\text { density }\end{array}$ & $\begin{array}{l}-21.33^{* * *} \\
(3.439)\end{array}$ & $\begin{array}{l}-159.50^{* * *} \\
(38.895)\end{array}$ & $\begin{array}{l}0.239 \\
(0.392)\end{array}$ & $\begin{array}{l}119.09^{* *} \\
(47.044)\end{array}$ & $\begin{array}{l}-0.174 \\
(43.517)\end{array}$ & $\begin{array}{l}-88.39^{*} \\
(53.312)\end{array}$ & $\begin{array}{l}-23.131 \\
(79.773)\end{array}$ & $\begin{array}{l}20.614 \\
(77.912)\end{array}$ \\
\hline Urbanisation & $\begin{array}{l}-0.083^{* * *} \\
(0.015)\end{array}$ & $\begin{array}{l}-0.088^{* * * *} \\
(0.029)\end{array}$ & $\begin{array}{l}0.003 \\
(0.002)\end{array}$ & $\begin{array}{l}0.002 \\
(0.029)\end{array}$ & $\begin{array}{l}-0.002 \\
(0.041)\end{array}$ & $\begin{array}{l}0.012 \\
(0.028)\end{array}$ & $\begin{array}{l}0.114 * * * \\
(0.039)\end{array}$ & $\begin{array}{l}0.117^{*} \\
(0.061)\end{array}$ \\
\hline $7-16$ year & $\begin{array}{l}-0.162 \\
(0.103)\end{array}$ & $\begin{array}{l}-0.123 \\
(0.244)\end{array}$ & $\begin{array}{l}-0.044 \\
(0.046)\end{array}$ & $\begin{array}{l}0.183 \\
(0.170)\end{array}$ & $\begin{array}{l}0.077 \\
(0.271)\end{array}$ & $\begin{array}{l}-0.124 \\
(0.194)\end{array}$ & $\begin{array}{l}0.133 \\
(0.248)\end{array}$ & $\begin{array}{l}-0.138 \\
(0.372)\end{array}$ \\
\hline $17-25$ year & $\begin{array}{l}-0.572^{* * *} \\
(0.105)\end{array}$ & $\begin{array}{l}-0.419^{*} \\
(0.251)\end{array}$ & $\begin{array}{l}0.010 \\
(0.039)\end{array}$ & $\begin{array}{l}-0.198 \\
(0.168)\end{array}$ & $\begin{array}{l}-0.302 \\
(0.277)\end{array}$ & $\begin{array}{l}-0.109 \\
(0.201)\end{array}$ & $\begin{array}{l}-0.337 \\
(0.251)\end{array}$ & $\begin{array}{l}-0.798^{* *} \\
(0.369)\end{array}$ \\
\hline 26-35 year & $\begin{array}{l}-0.486^{* * *} \\
(0.123)\end{array}$ & $\begin{array}{l}-0.344 \\
(0.292)\end{array}$ & $\begin{array}{l}-0.041 \\
(0.047)\end{array}$ & $\begin{array}{l}-0.132 \\
(0.195)\end{array}$ & $\begin{array}{l}-0.046 \\
(0.319)\end{array}$ & $\begin{array}{l}-0.015 \\
(0.240)\end{array}$ & $\begin{array}{l}-0.230 \\
(0.300)\end{array}$ & $\begin{array}{l}-0.570 \\
(0.441)\end{array}$ \\
\hline 36-66 year & $\begin{array}{l}-0.361 * * * \\
(0.112)\end{array}$ & $\begin{array}{l}0.033 \\
(0.246)\end{array}$ & $\begin{array}{l}-0.024 \\
(0.036)\end{array}$ & $\begin{array}{l}-0.046 \\
(0.180)\end{array}$ & $\begin{array}{l}-0.420 \\
(0.282)\end{array}$ & $\begin{array}{l}-0.126 \\
(0.220)\end{array}$ & $\begin{array}{l}-0.579 * * \\
(0.277)\end{array}$ & $\begin{array}{l}-0.639 \\
(0.401)\end{array}$ \\
\hline $67+$ year & $\begin{array}{l}-0.890^{* * *} \\
(0.123)\end{array}$ & $\begin{array}{l}-0393 \\
(0.278)\end{array}$ & $\begin{array}{l}-0.077 * * \\
(0.038)\end{array}$ & $\begin{array}{l}0.052 \\
(0.195)\end{array}$ & $\begin{array}{l}-0.175 \\
(0.321)\end{array}$ & $\begin{array}{l}-0.083 \\
(0.216)\end{array}$ & $\begin{array}{l}-0.305 \\
(0.295)\end{array}$ & $\begin{array}{l}-0.819^{*} \\
(0.453)\end{array}$ \\
\hline Widowed & $\begin{array}{l}-0.230 \\
(0.146)\end{array}$ & $\begin{array}{l}-0.369 \\
(0.312)\end{array}$ & $\begin{array}{l}0.082^{*} \\
(0.043)\end{array}$ & $\begin{array}{l}-0.188 \\
(0.244)\end{array}$ & $\begin{array}{l}-0.403 \\
(0.366)\end{array}$ & $\begin{array}{l}-0.452^{*} \\
(0.239)\end{array}$ & $\begin{array}{l}-0.048 \\
(0.319)\end{array}$ & $\begin{array}{l}-0.139 \\
(0.455)\end{array}$ \\
\hline Divorced & $\begin{array}{l}-0.807 * * * \\
(0.111)\end{array}$ & $\begin{array}{l}-1.358^{* * *} \\
(0.229)\end{array}$ & $\begin{array}{l}0.063^{* *} \\
(0.029)\end{array}$ & $\begin{array}{l}-0.260 \\
(0.197)\end{array}$ & $\begin{array}{l}0.643^{* *} \\
(0.295)\end{array}$ & $\begin{array}{l}-0.114 \\
(0.194)\end{array}$ & $\begin{array}{l}0.428 \\
(0.270)\end{array}$ & $\begin{array}{l}0.649 \\
(0.397)\end{array}$ \\
\hline Unmarried & $\begin{array}{l}-0.655^{* * *} \\
(0.077)\end{array}$ & $\begin{array}{l}-0.260 \\
(0.172)\end{array}$ & $\begin{array}{l}-0.001 \\
(0.022)\end{array}$ & $\begin{array}{l}-0.089 \\
(0.122)\end{array}$ & $\begin{array}{l}-0.357^{*} \\
(0.189)\end{array}$ & $\begin{array}{l}-0.121 \\
(0.139)\end{array}$ & $\begin{array}{l}-0.029 \\
(0.188)\end{array}$ & $\begin{array}{l}0.100 \\
(0.270)\end{array}$ \\
\hline Adult children & $\begin{array}{l}0.235^{* * *} \\
(0.048)\end{array}$ & $\begin{array}{l}-0.035 \\
(0.109)\end{array}$ & $\begin{array}{l}0.021 \\
(0.020)\end{array}$ & $\begin{array}{l}-0.112 \\
(0.077)\end{array}$ & $\begin{array}{l}0.188 \\
(0.121)\end{array}$ & $\begin{array}{l}0.233^{* *} \\
(0.091)\end{array}$ & $\begin{array}{l}0.080 \\
(0.120)\end{array}$ & $\begin{array}{l}-0.019 \\
(0.174)\end{array}$ \\
\hline No children & $\begin{array}{l}0.376 \\
(0.410)\end{array}$ & $\begin{array}{l}2.264^{*} \\
(1.218)\end{array}$ & $\begin{array}{l}-0.719 * * * \\
(0.241)\end{array}$ & $\begin{array}{l}-0.027 \\
(0.860)\end{array}$ & $\begin{array}{l}0.452 \\
(1.331)\end{array}$ & $\begin{array}{l}-0.961 \\
(0.759)\end{array}$ & $\begin{array}{l}0.639 \\
(1.067)\end{array}$ & $\begin{array}{l}-2.808^{*} \\
(1.695)\end{array}$ \\
\hline Educated & $\begin{array}{l}-0.025 \\
(0.041)\end{array}$ & $\begin{array}{l}-0.066 \\
(0.091)\end{array}$ & $\begin{array}{l}0.010^{*} \\
(0.006)\end{array}$ & $\begin{array}{l}-0.122^{*} \\
(0.063)\end{array}$ & $\begin{array}{l}-0.050 \\
(0.102)\end{array}$ & $\begin{array}{l}-0.179 * \\
(0.092)\end{array}$ & $\begin{array}{l}0.030 \\
(0.106)\end{array}$ & $\begin{array}{l}0.117 \\
(0.177)\end{array}$ \\
\hline $\begin{array}{l}\text { Social disability } \\
\text { pensioned }\end{array}$ & $\begin{array}{l}-0.118 \\
(0.076)\end{array}$ & $\begin{array}{l}-0.378^{* *} \\
(0.152)\end{array}$ & $\begin{array}{l}0.003 \\
(0.015)\end{array}$ & $\begin{array}{l}-0.019 \\
(0.130)\end{array}$ & $\begin{array}{l}-0.057 \\
(0.211)\end{array}$ & $\begin{array}{l}-0.064 \\
(0.129)\end{array}$ & $\begin{array}{l}0.485^{* * *} \\
(0.184)\end{array}$ & $\begin{array}{l}0.032 \\
(0.269)\end{array}$ \\
\hline Social benefit & $-0.134 * * *$ & $-0.229 * *$ & 0.009 & 0.046 & 0.095 & -0.100 & 0.102 & 0.011 \\
\hline
\end{tabular}




\begin{tabular}{|c|c|c|c|c|c|c|c|c|}
\hline receivers & $(0.041)$ & $(0.092)$ & $(0.014)$ & $(0.071)$ & $(0.107)$ & $(0.069)$ & $(0.093)$ & $(0.145)$ \\
\hline Unemployed & $\begin{array}{l}0.072 \\
(0.048)\end{array}$ & $\begin{array}{l}-0.046 \\
(0.109)\end{array}$ & $\begin{array}{l}0.011 \\
(0.020)\end{array}$ & $\begin{array}{l}0.084 \\
(0.086)\end{array}$ & $\begin{array}{l}0.101 \\
(0.130)\end{array}$ & $\begin{array}{l}0.116 \\
(0.077)\end{array}$ & $\begin{array}{l}0.220 * * \\
(0.097)\end{array}$ & $\begin{array}{l}-0.002 \\
(0.156)\end{array}$ \\
\hline 3rd countries & $\begin{array}{l}-0.045^{* * *} \\
(0.008)\end{array}$ & $\begin{array}{l}-0.055^{* * *} \\
(0.019)\end{array}$ & $\begin{array}{l}-0.002 \\
(0.002)\end{array}$ & $\begin{array}{l}-0.001 \\
(0.013)\end{array}$ & $\begin{array}{l}0.048^{* *} \\
(0.021)\end{array}$ & $\begin{array}{l}-0.015 \\
(0.017)\end{array}$ & $\begin{array}{l}-0.008 \\
(0.021)\end{array}$ & $\begin{array}{l}-0.034 \\
(0.031)\end{array}$ \\
\hline LogL & -681.86 & -477.66 & & & & & & \\
\hline AIC & 1463.73 & 1391.32 & & & & & & \\
\hline $\mathrm{R}^{2}$ & 0.922 & 0.943 & & & & & & \\
\hline $\bar{\lambda}$ & $\begin{array}{l}0.205^{* * *} \\
(0.074)\end{array}$ & $\begin{array}{l}0.095 \\
(0.099)\end{array}$ & & & & & & \\
\hline Diag. test & & $273.38^{* * * *}$ & & & & & & \\
\hline Expansion test & & & $94.56^{* * * *}$ & $314.24 * * *$ & & & & \\
\hline
\end{tabular}

Note. Standard errors in parentheses. Significance indicated by $*(10 \%),{ }^{* *}(5 \%), * * *(1 \%)$.

Test for diagonality is a Wald test; tests for expansions are LR tests.

For a model with $\left(\alpha_{0}, \alpha_{T}\right)$ only, $\log \mathrm{L}=-634.58, \mathrm{AIC}=1425.17$, and $\mathrm{R}^{2}=0.928$. 


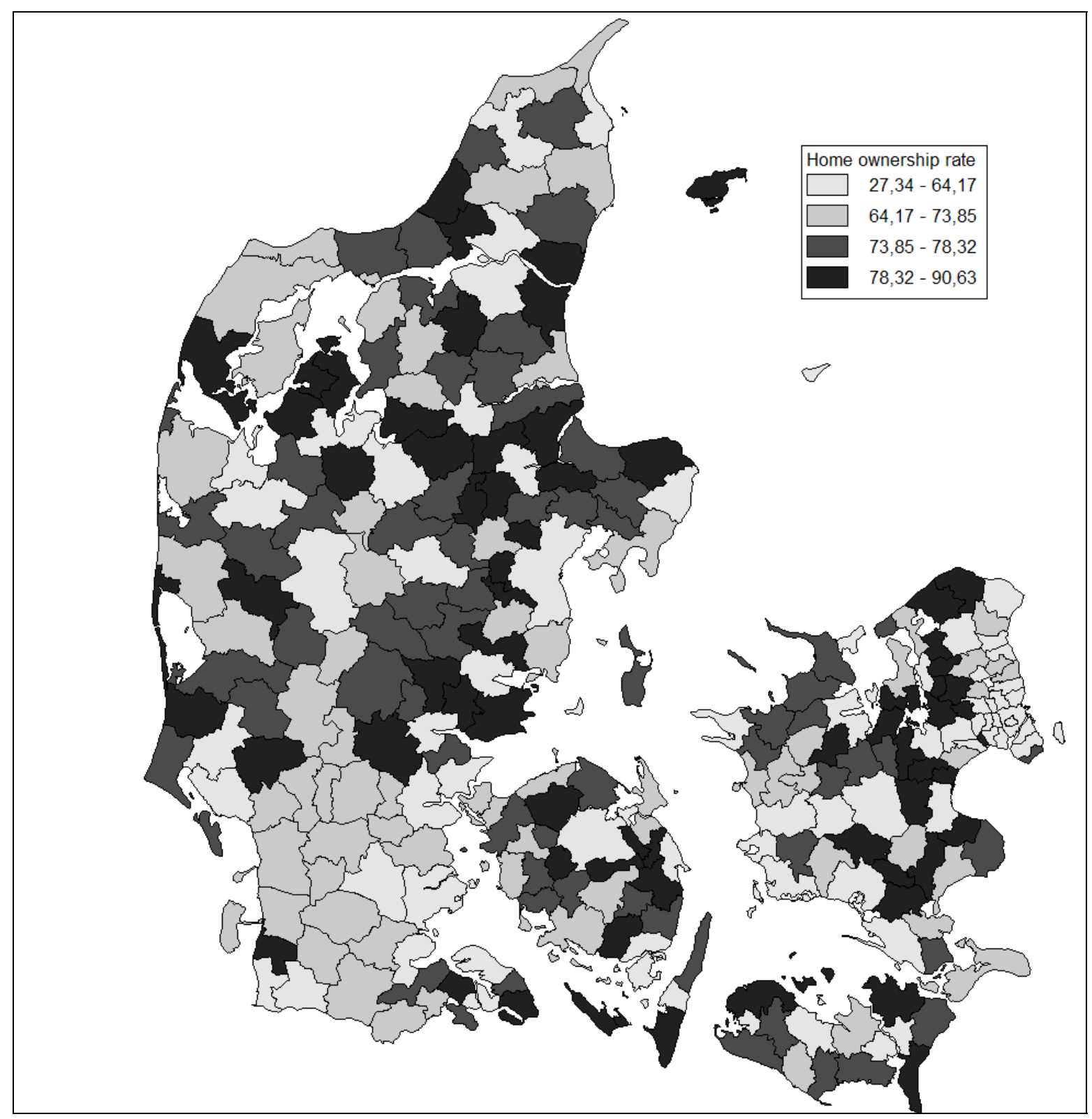

Figure 1. Geographical distribution of home ownership rates (average 1999-2004) 

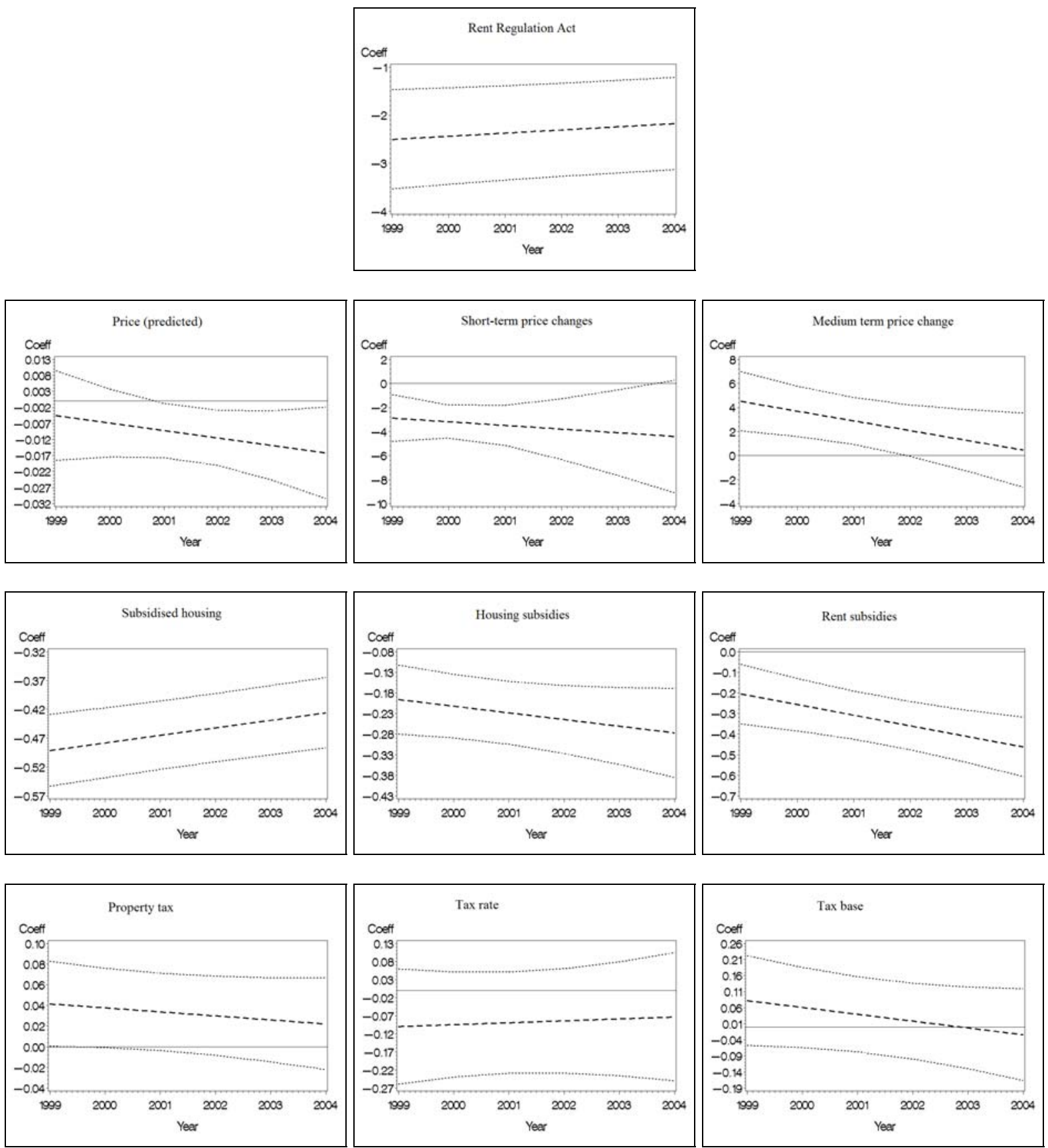

Figure 2. Coefficients by year (average for 270 municipalities) 

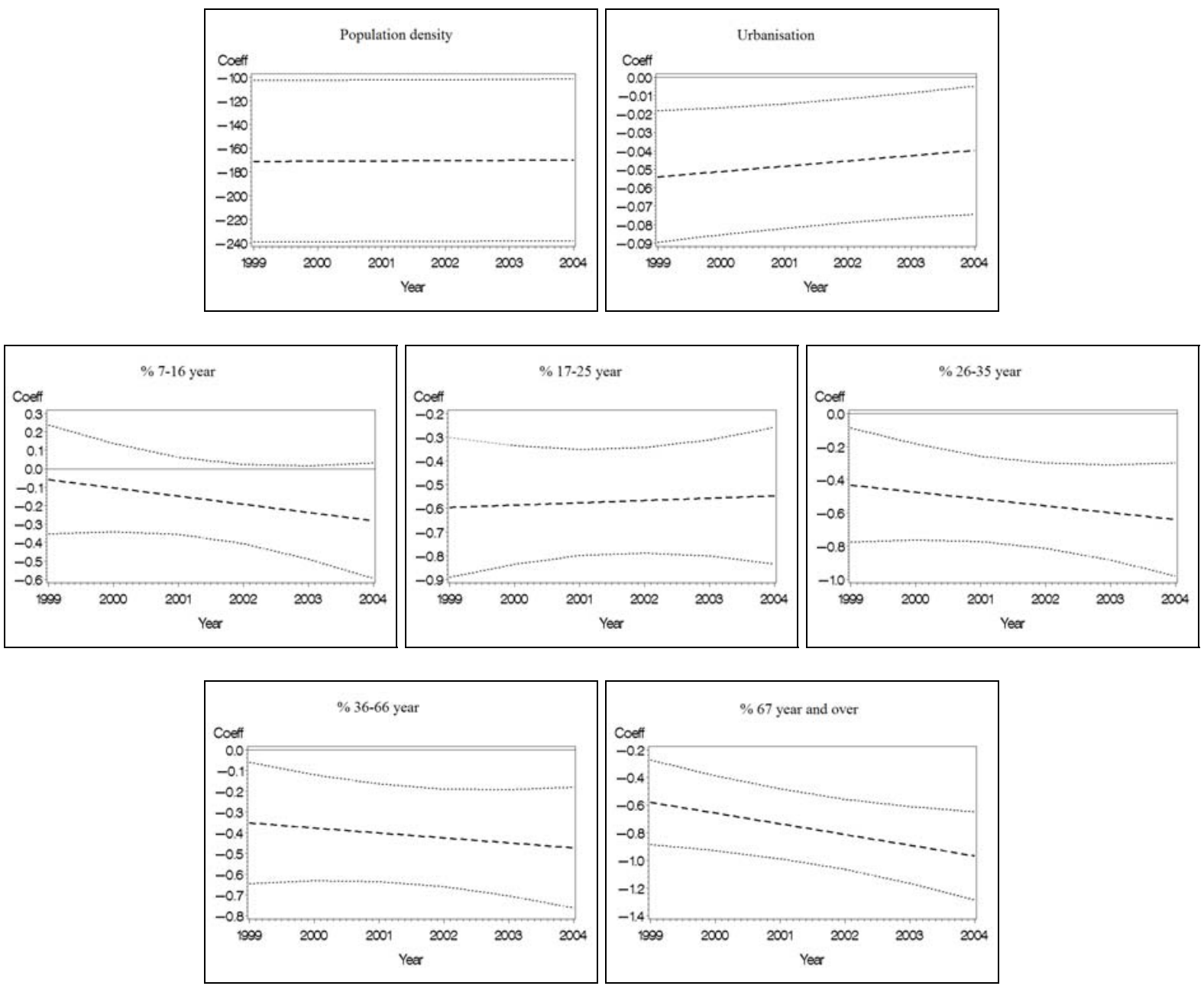

Figure 2. (continued) 

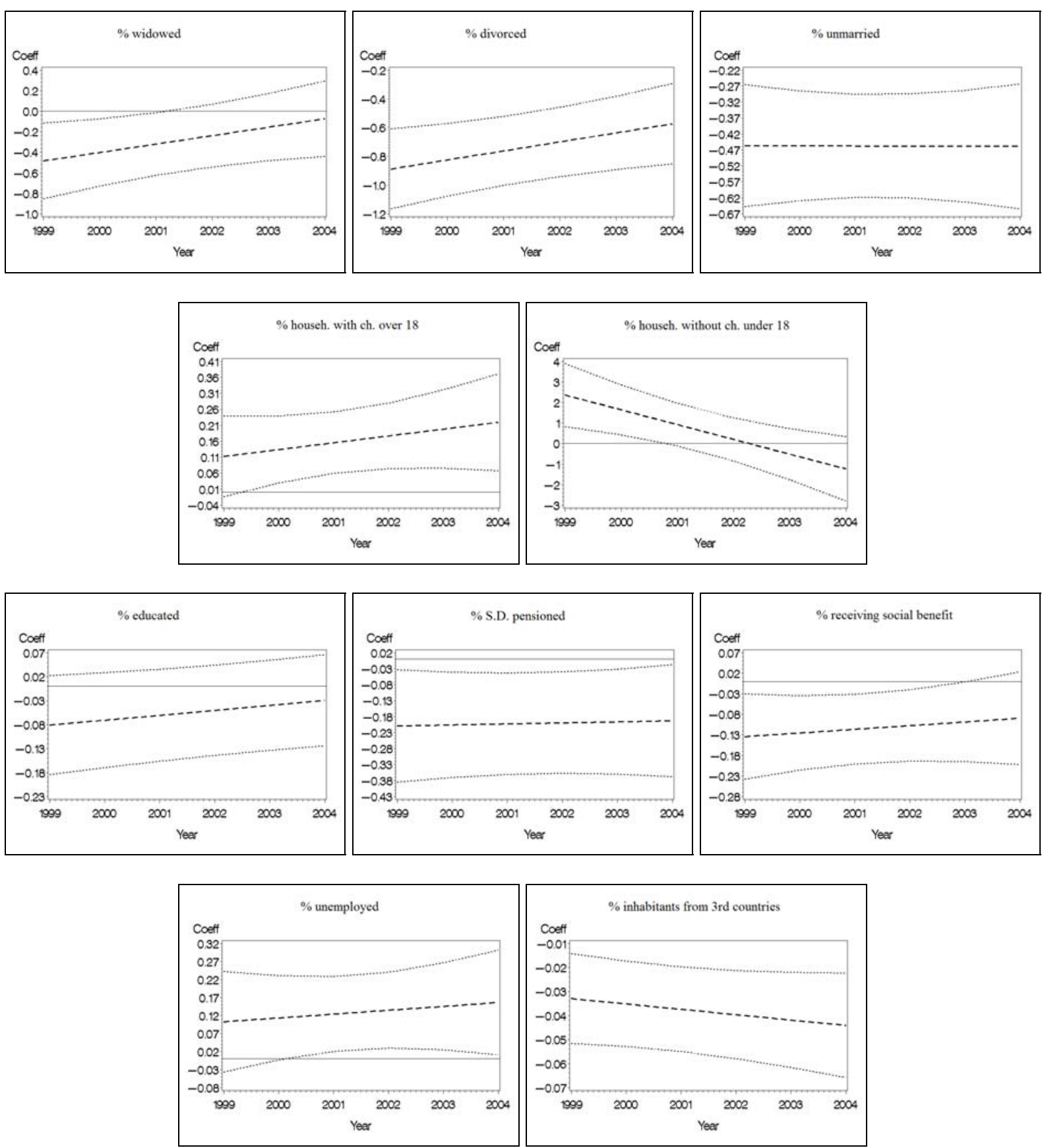

Figure 2. (continued) 

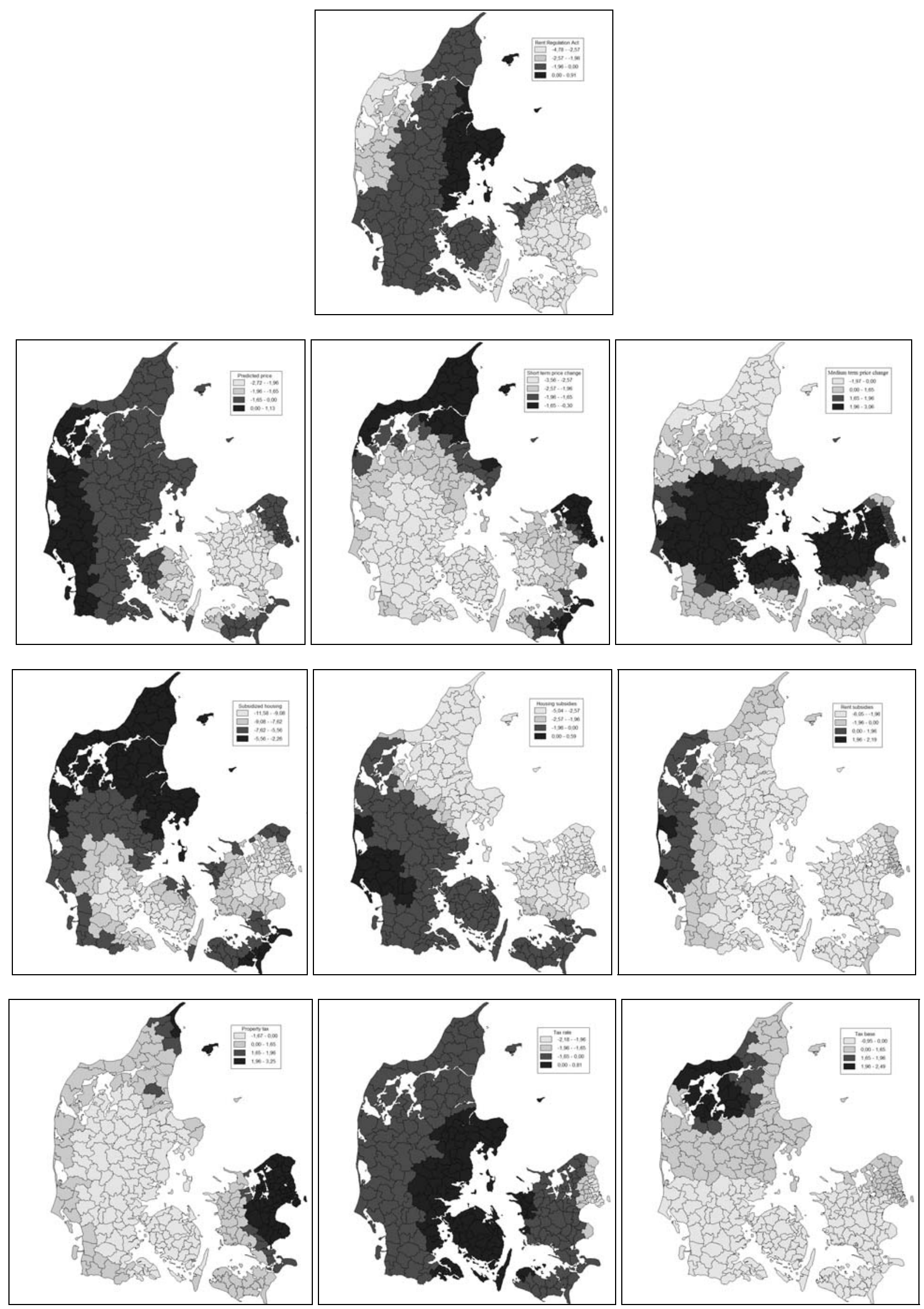

Figure 3. T values of coefficients (average 1999-2004) by municipality 

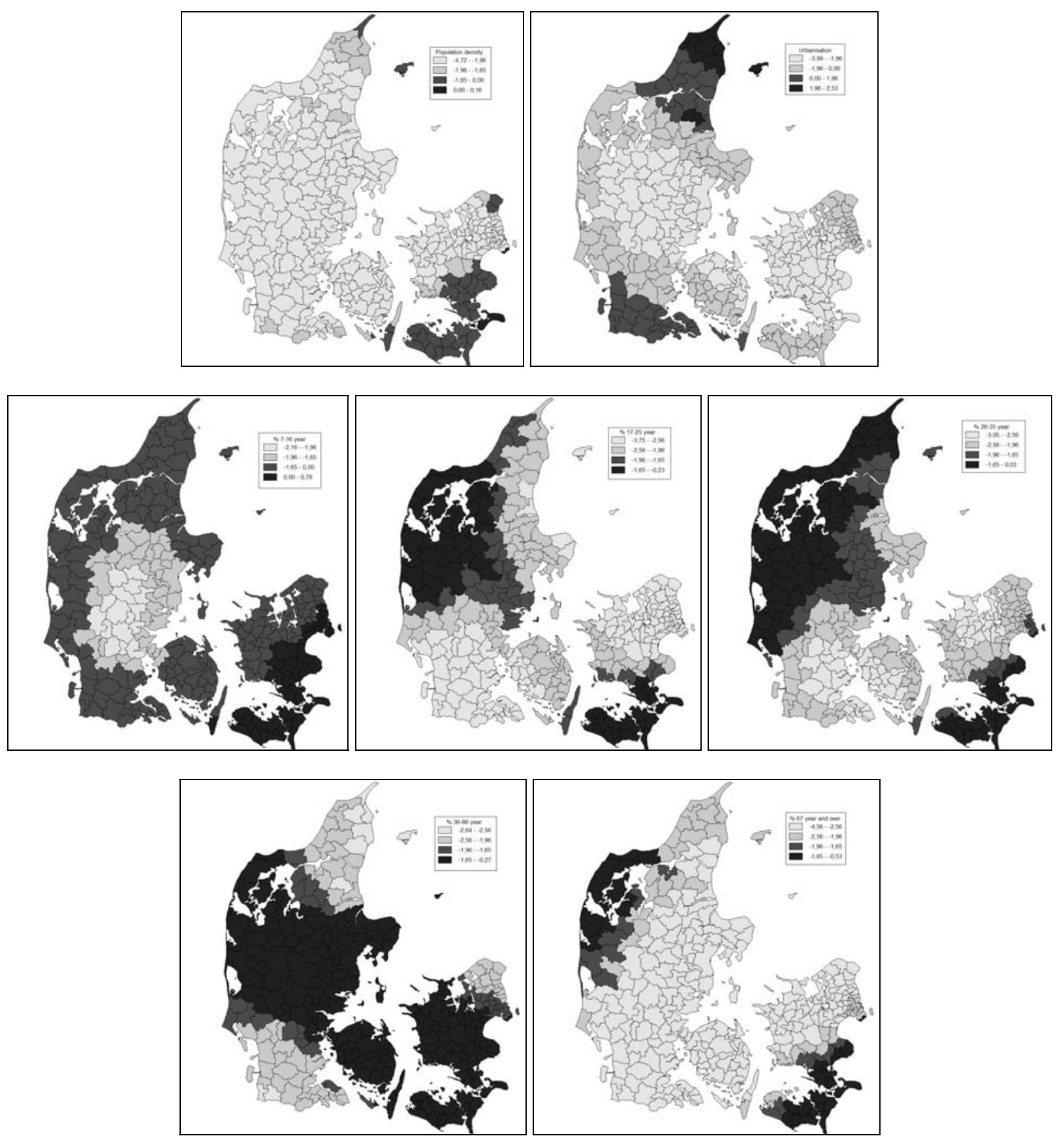

Figure 3. (continued) 

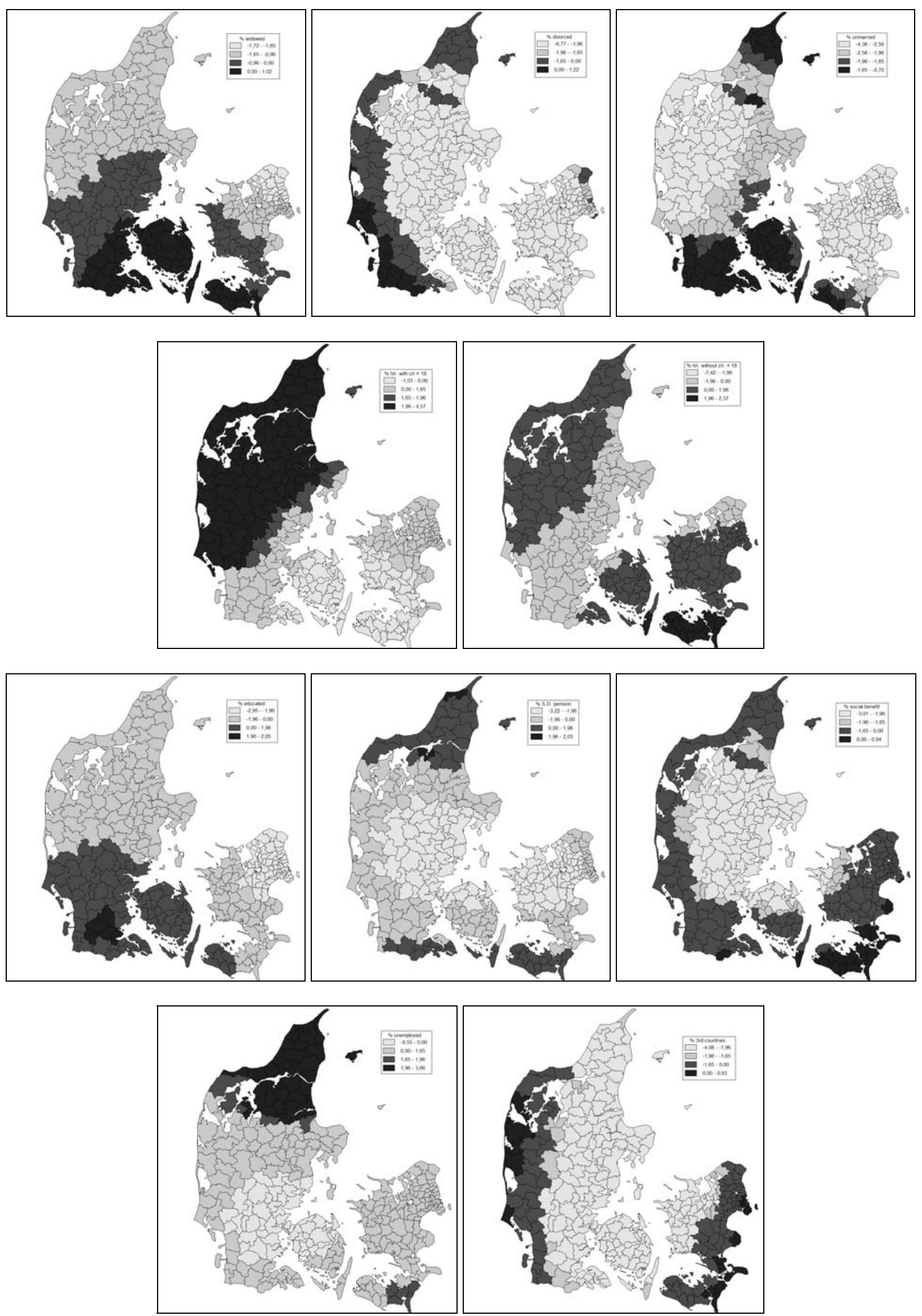

Figure 3. (continued) 


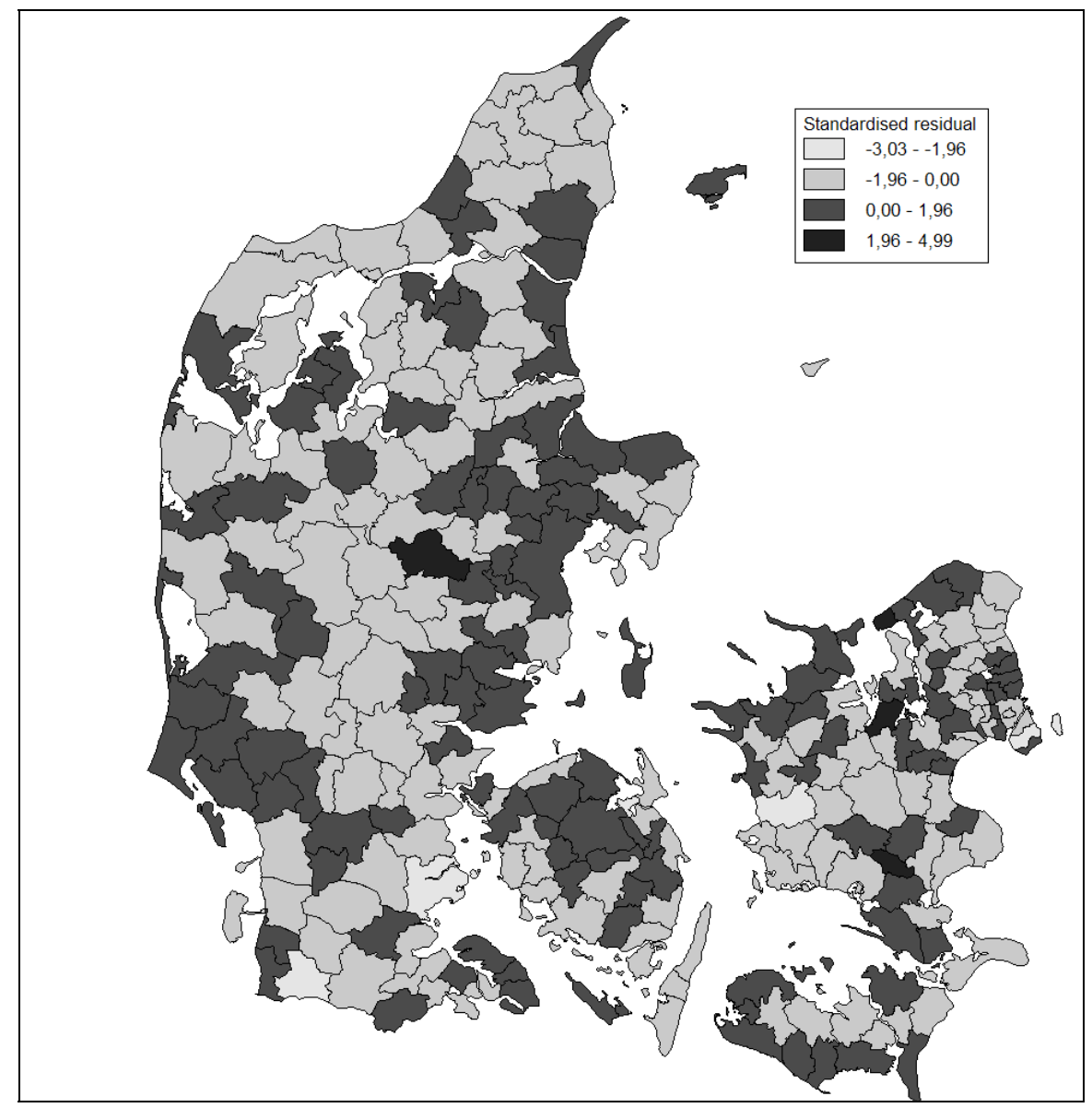

Figure 4. Standardised residuals (average 1999-2004) by municipality 